\title{
Research on Teaching Management Reform in Local Colleges and Universities
}

\author{
Liping Yin \\ School of Humanities, Jilin Agricultural University, Changchun 130118, China \\ 5289977@qq.com
}

\begin{abstract}
With the advance of the education reform and the promotion of the globalization, the reform of local Colleges and universities is urgent. This paper mainly analyses the present situation of the reform of teaching management in local Colleges and universities, finds out the existing problems, analyzes the reasons for these problems, and finds out that modern teaching management concept has not been really established, the environment for the development of teaching management has not been really optimized, and the development background of teaching management has not been really formed. This paper proposes four suggestions of establishing a scientific and modernized teaching management concept, improving the school and college level teaching management system, constructing high quality teaching and management team, and really improving and optimizing the teaching management team and occupation development conditions.
\end{abstract}

Keywords: Local Colleges and universities; Teaching management; Reform.

\section{Introduction}

The wave of globalization makes China's higher education face the challenge and impact, and puts forward the urgent request to the teaching management work. China's higher education is under the background of the globalization of higher education and facing the challenge of internationalization and globalization of higher education. This situation has promoted the exchange and cooperation of countries in the field of education, and promoted the opening and competition of the education market. The world has formed the situation of increasingly fierce competition for talents, and the trend of internationalization of this kind of education will beyond doubt cause significant impact on developing higher education pupils' competitiveness and talents reservation. As a result, our country, on the basis of referring to and learning of European higher education reform experiences and lessons, carries out in-depth reform of higher education, while the reform without doubt puts forward new requirements and new challenges for the teaching management in Colleges and universities.

\section{Present Situation of Teaching Management Reform in Local Colleges and Universities}

Overall speaking, with the continuous deepening of the development of teaching reform, the teaching management of local Colleges and universities has been further improved. The teaching management concepts, teaching management team construction, teaching management system optimization, teaching management theory research have been improved and the situation of education and teaching management has been further enhanced.

\subsection{Backward Concept of Teaching Management and Insufficient Understanding of the Importance of Teaching Management}

Through the investigation, it is known that many local Colleges and universities has not really set up the modern teaching management concept, involving in the investigation of teaching management personnel duty. That believes it is the "service" is $40.5 \%$, and that teaching managers thinks themselves as "managers" is $59.5 \%$. Therefore, most of roles positioning of the staff of teaching management work in the subconscious is still the manager rather than the servant, which is bound to make it have strong management in the specific work and lacks awareness of service. In addition, the teaching management work cannot be fully or correctly recognized. When asked about the understanding of the work of teaching management, $13.5 \%$ of teaching management staffs believe that teaching management is a simple and repetitive administrative work. In the process of 
investigation, when asked about the impact factors for quality of teaching management work, $75 \%$ of the people think that it is related to the teaching facilities and pupils, and only $25 \%$ of the staffs believe that the level of teaching management is an important factor affecting the quality of teaching management.

\subsection{Not Smooth Teaching Management System Operation of School and College Two Levels}

Teaching management responsibilities of school and college two levels are unclear. Management theory believes that the responsibility and right are corresponding is the important principle of management, and it is also the basic guarantee and requirement of Colleges implementing teaching management of school and college two levels. Scientific right and responsibility allocation system is the soul of the construction of management system of the two levels of school and college, and it is also the key for if the management system of the two levels of school and college is scientific and rational.

\subsection{Not High Teaching Management Team and Irrational Age Structure}

The completion of the goal of teaching management, the implementation of the policy system, the improvement of teaching management level and so on are directly proportional to the enhancement of the quality of teaching management. That is to say, the quality of teaching management personnel directly affects the enhancement of teaching management level. However, through interviews and questionnaire survey to the teaching management of local Colleges and universities, it is known that although the quality of teaching management team personnel although has been improved to some degree, there are still many problems, specifically shown as irrational and not high quality of teaching management professional background structure, not high academic level, and unreasonable teaching management personnel age the structure.

\subsection{Difficult Professional Title Promotion of Teaching Management Personnel, Unreasonable structure, and Low Sense of Achievement}

At present, the local university teaching management personnel are divided into two categories, one is the 2-shoulder-loaded personnel above deputy high title and the deputy director position, the other is the working staffs engaged in full-time management. Most people said that it is difficult to have the title promotion, 2-shoulder-loaded personnel take a lot of administrative management work, inadequately invest in teaching research and innovation of teaching method of classroom teaching mode, and because the administrative is in office and the amount of hours is also inadequate, these two aspects are contradictory both in time and energy. Generally speaking, the overall difficulty of teaching management staffs to promote the title is great, and for some management staffs in basic level, the title is even just the expectation but unable to obtain as shown in Table 1-3 [1].

Table 1 Sense of achievement of teaching management work

\begin{tabular}{|c|c|c|}
\hline Comparatively great & No & Just a little \\
\hline $9.30 \%$ & $68.30 \%$ & $22.40 \%$ \\
\hline
\end{tabular}

Table 2 Satisfaction degree of teaching management work

\begin{tabular}{|c|c|c|c|}
\hline Dissatisfied & Basically satisfied & Comparatively satisfied & Quite satisfied \\
\hline $53.10 \%$ & $23.70 \%$ & $18.10 \%$ & $5.10 \%$ \\
\hline
\end{tabular}

Table 3 Enthusiasm of teaching management work

\begin{tabular}{|c|c|c|c|}
\hline Quite high & Comparatively high & Just a little & No \\
\hline $9.20 \%$ & $13.70 \%$ & $36.40 \%$ & $40.70 \%$ \\
\hline
\end{tabular}

\subsection{Frequent Flow of the Teaching Management Personnel and Not Strong Stability}

The occupation outlook survey data shows that the those who choose bright future and comparatively optimistic options only occupies $6.7 \%, 48 \%$ of people said "If there is a chance, they are very willing or willing to leave teaching management positions; $35.8 \%$ of the staffs said that if possible, they will consider to leave; in the option of not considering, it is only $2 \%$. Especially the excellent teaching management staffs with above deputy high title or deputy director position, have great flowing. They position the teaching management work as their "temporary work", and take it as 
a temporary "pedal". There are up to $86.3 \%$ of the staffs in such kind of teaching management personnel are not willing to stay in the teaching management positions for too long a time, and once there is an opportunity, they are very willing to leave the teaching management position.

\section{Analysis of the Causes of Problems in Teaching Management Reform in Local Colleges and Universities}

\subsection{Not Really Established Concept of Modern Teaching Management}

The scientific and people-oriented management of "taking students as the main body" and "taking the teacher as the leading" is the core idea of modern teaching management. Lishui University, in the actual teaching management work, has not really established the management spirit of "scientific management" and "people-oriented" [2]. In the specific management work, the effectiveness of school management has not been taken into account. They only pay attention to the work of the school teaching management and just get things done, while do not consider the efficiency and level of management. At the same time, the idea of teaching management is still emphasizing official standard while despising service, still in the phase of experience management and form management, teaching management does not discuss how to establish and perfect various rules and regulations on the basis of reflecting humanistic spirit, and ensure the implementation. It can be said that the concept of teaching management is in a low layer and low level operation state. It leads to the school, in the specific teaching management process, pays little attention to the awareness of main body of the teaching management, which is extremely unfavorable for the development of the school teaching management.

\subsection{Not really Optimized Development Environment of Teaching Management}

The importance of the development of teaching management has not been recognized enough. The development of teaching management has not been paid attention to in the practical work, most school leaders only improves the teaching management work requirements and focuses on the outcome, but in the actual operation, they do not pay attention to the realization of teaching management professional, which results in that the development of teaching management level is very low.

\subsection{Not Really Formed Background of Development of Teaching Management}

The teaching management rules and regulations construction of many Colleges and universities lag behind the development of teaching management, and the content of the system is relatively vague. Even if there is the implementation of the system, it is not optimistic. The factors for the above results are divided into the following two aspects: first of all, it does not really establish the concept of "people-oriented", "matters-oriented" concept is ingrained and long-term passive work habits lead to work lack of initiative and innovation. Secondly, the teaching management system and the operating mechanism lack flexibility.

\section{Countermeasures of Promoting the Development of Teaching Management in Local Colleges and Universities}

\subsection{Set up Scientific and Modern Teaching Management Idea}

Idea is the guide of action. Setting up scientific teaching management concept, forming correct understanding, and carrying out scientific role orientation are the key to realize the development of teaching management work.

Scientifically position the role of the teaching management staffs. In the face of the current development needs of Colleges and universities, pure management has not been able to play the role of teaching management. The teaching management staff is not only the former "managers", instead, they also have the status of the service providers. Therefore, to further clarify the role of teaching management, to grasp the relevant knowledge and skills, is of great significance to improve the efficiency and effectiveness of teaching and teaching management and promote the establishment of scientific management system and the formation of mechanism [3]. 
Establish the management concept of people-oriented. In Colleges and universities, people-oriented teaching management concept is mainly reflected in the maintaining teachers' and students' subject status, giving full consideration to needs and interests of teachers and students and teaching management personnel, respecting for the law of education and teaching, and giving more humanistic care for them. By ensuring the right of teachers and students to participate in the democratic management of the school, so teachers and students participate in the process of teaching management and express their aspirations, to achieve the function of mutual promotion and form an organic whole of democracy. The concept of people-oriented is infiltrated to the teaching management practice and the construction and perfect of the teaching management system

Scientifically and systematically understand the work of teaching management in Colleges and Universities. The teaching work is the central work of Colleges and universities, and the main way to carry out the teaching work is the teaching management activities. Therefore, we must respect the inherent law of teaching management work, and scientifically make clear the basic task, purpose and basic method of teaching management work. Establish and improve the scientific management system of higher education development.

\subsection{Perfect the Teaching Management System of Two Levels of School and College}

With the expansion of the scale of higher education, the strength and level of running a school of local Colleges and universities has entered a new historical stage, while the teaching management workload is greatly increasing and also the difficulty. The traditional management mechanism that takes teaching management department of university as the leading and a compulsory management mode can't meet the needs of management. Secondly, with the establishment and extension of modern university system, Colleges emphasize the academic freedom and the service functions of the administration, and the implementation of the two-level management is an important embodiment of the trend of the modern university system construction. In the end, the demand of the development of social economy for diversified talents is becoming more and more important. "Multi discipline and multi-specialty" has become an important feature of the school running mode. The difference between subjects determines the difference of teaching methods, so the teaching management of the two levels of school and college also has its own characteristics [4]. All these situations require the school to implement the two-level teaching management system, so as to better serve the talent training. In consequence, it is necessary to deepen the reform of teaching management institutions, to clarify the school's teaching management responsibilities and rights, and to establish and improve the teaching management system for the two level of teaching management system.

\subsection{Construct Teaching Management Team with High Quality}

From the survey data analysis, teaching management staffs shortage results in that the school teaching management work efficiency is not high, delaying the teaching management reform, so reasonably collocate the number of the school teaching management staffs is the basis and precondition to realize the construction of teaching management team in the school and guarantee stable management staffs team. First of all, the number of university students is greatly increasing caused by gradual expanded scale of running school, according to the number of students, scientifically develop the collocation standard for teaching management personnel, and in human resources to ensure to meet the needs of teaching management work; secondly, scientifically make staffs mechanism, based on the reality of the development of school, teaching management reform, and practical needs, fully demonstrated by science, according to the demand of teaching management staffs in teaching management to determine their duties; thirdly, according to the long-term development planning, scientifically develop teaching management personnel development plan, so as to ensure the stable development of teaching management team. Further optimize the structure of teaching management team. Only reasonable structure of College teaching management team can play the enthusiasm of teaching and management of the individual and the overall advantages of the management team. 


\subsection{Effectively Improve and Optimize Teaching Management Team Treatment and Professional Development Conditions}

Improve the teaching management staff's welfare treatment, salary income and working motivation. An important factor that affects the teaching management staffs to choose to be engaged in teaching management is the welfare treatment and salary of teaching management position. The influence of high or low position on teaching management staffs is reflected in that the higher job tittle, the stronger the working motivation. The more basic level the teaching management workers, the weaker the teaching management work level [5].

Perfect teaching management personnel training and learning mechanism. The era of knowledge economy is the era of knowledge explosion, which leads to each profession no matter in the specialized field or technological field maintains the state of learning. Universities should take various training ways to construct scientific, perfect, and rich teaching management personnel, realize professional talents introduction, training before on-job, self-learning, and short-term training of full-time education and other forms of training, so as to realize planned, targeted, and long-term effective training system, and achieve the professional development of the teaching management team.

\section{Conclusion}

The development of higher education cannot be separated from the reform and innovation of teaching management. With the rapid development of social economy and science and technology, with the popularization and internationalization of higher education in our country, the reform of teaching management in local Colleges and universities has become the inevitable trend of development. Through the research in the paper, it is concluded the strategies for the reform and development: set up a scientific and modern teaching management concept, improve teaching management system of two levels of school and college, construct high quality teaching and management team, and improve and optimize the teaching management team and occupation development conditions.

\section{References}

[1] Hayden M, Thompson J. International schools and international education: Improving teaching, management and quality [M]. Routledge, 2013.

[2] Li Z, Shen H. Database Design on Teaching Management System Based on SQL Server [J]. 2016.

[3] Trout a T, Cohan R H, Ellis J H, et al. Teaching management of contrast reactions: does it work and how often do we need to refresh? [J]. Academic radiology, 2012, 19(4): 498-504.

[4] Chen D L, Chen L, Ji Q F. The Experimental Teaching Based on Hybrid Cloud Management System Research[C]//Applied Mechanics and Materials. Trans Tech Publications, 2013, 347: 2257-2260.

[5] Oral B. Student teachers' classroom management anxiety: A study on behavior Management and teaching management [J]. Journal of Applied Social Psychology, 2012, 42(12): 2901-2916. 